\title{
Erratum
}

\section{In vitro culture of Foeniculum vulgare: callus characteristics in relation to morphogenesis}

\author{
M. Anzidei, L. Vivona, S. Schiff \& A. Bennici \\ Plant Biology Department, University of Florence, P. le Cascine 28-50144 Florence, Italy \\ Plant Cell, Tissue and Organ Culture Volume 45, No. 3, pp. 263-268 (June 1996)
}

On page 267 of the original article the National Research Council Special Project number was unfortunately omitted. The full text of the Acknowledgements is published below.

\section{Acknowledgements}

The authors are grateful to C. Tani and B. Mori for their invaluable technical assistance in the cytological and histological methodology. This research was supported by the National Research Council of Italy, Special Project RAISA, Sub-project N.2, Paper N. 2536. 